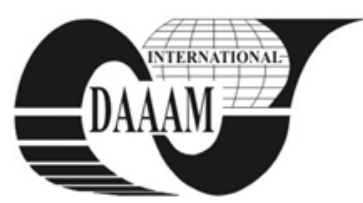

Annals of DAAAM for 2012 \& Proceedings of the 23rd International DAAAM Symposium, Volume 23, No.1, ISSN 2304-1382 ISBN 978-3-901509-91-9, CDROM version, Ed. B. Katalinic, Published by DAAAM International, Vienna, Austria, EU, 2012 Make Harmony between Technology and Nature, and Your Mind will Fly Free as a Bird Annals \& Proceedings of DAAAM International 2012

\title{
STUDY OF THE EVOLUTION OF THE AIR TEMPERATURE IN MOLDAVIA REGION (ROMANIA) OVER THE LAST 67 YEARS
}

\author{
MACHIDON, O[vidiu]; APOSTOL, L[iviu]; MACHIDON, D[ana] \& BURUIANA, D[aniel]
}

\begin{abstract}
This paper presents evolution in time and trends of the average of air temperature and the number of days with different category of the air temperature, in the region of Moldavia (Romania), during the 1945-2011 period. The data, uninterruptedly measured by the seven weather stations within the 67-year period, is summarized in tables, and their interpretation is supported by graphics. The study concludes that the annual average of air temperature has been continuously increasing over the last 67 years.

Keywords: air temperature, evolution, trends
\end{abstract}

\section{INTRODUCTION}

In the first decade of the 21st century, Moldavia faced an unprecedented sequence of hot periods and very moist and rainy periods. Some of them surpassed the relevant meteorological observation. Air temperature is one of the most important factors that have influence on human activity.

This is the first study ever to be conducted on the evolution of air temperature over a 67 -year period in Moldavia (Romania). The problem of the air temperature tendence in Romania problem was approached 120 years ago yet [6]. For the Central-East European aria [4] and for whole territory of Romania [5, 7, 8, 9], temperature variations and tendencies was studied. The National Meteorological Administration in Romania has recently conducted an assessment of the current climate in Romania, featuring the air temperature, mainly in terms of its territorial distribution and secondly regarding its time evolution [11]. For the different parts of the Moldavia, different analyses of the air variations and temperatures was made $[1,2,3,10]$.

The region of Moldavia is a territory in Northeastern Romania with an area of $35.806 \mathrm{~km}^{2}$. To highlight the differences between the periodic evolution of air temperature average values and the time evolution of the days with minimum air temperature $\leq-10{ }^{0} \mathrm{C}$, maximum air temperature $\leq 0{ }^{0} \mathrm{C}$, maximum air temperature $\geq 30{ }^{0} \mathrm{C}$ and minimum air temperature $\geq 20{ }^{0} \mathrm{C}$, data from the 1945-2011 period, being the most consistent, have been used, However, it was taken into consideration the fact that the weather stations are located in the most different geographical and physical conditions (Fig 1).

This paper is primarily based on factual material represented by data continually measured throughout the 1945-2010 period by the Moldavian weather stations in the capitals of the different counties, Botosani, Suceava, Iasi, Piatra Neamt, Bacau, Barlad and Galati [7]. The spatial repartition are good, but the altitudinal distribution is not so representative because the mountain meteorological station have not an so long data observations. The data is summarized in tables and their interpretation is supported by graphs. The statisticalmathematical processing of the climatic data and their graphical representation are the methods through which the corpus of data collected from the weather stations measurements has been developed. Furthermore, both methods were used in the graphical transposition of the results obtained by averaging the data from the seven weather stations. In order to establish a trend, we have used the method of moving averages, on a time series of 10 years, shifted with a year calculated by averaging the values recorded by those weather stations. The trend line has been drawn by using EXCEL.

We look forward to continuing the research on the temporal and special evolution of the meteorological phenomena of risk, such as hail, storms, droughts, etc., in the current context of the climate change in Moldavia (Romania). The research results are highly significant, not only for agriculture, but also for economy, overall investment sector and human life in general.

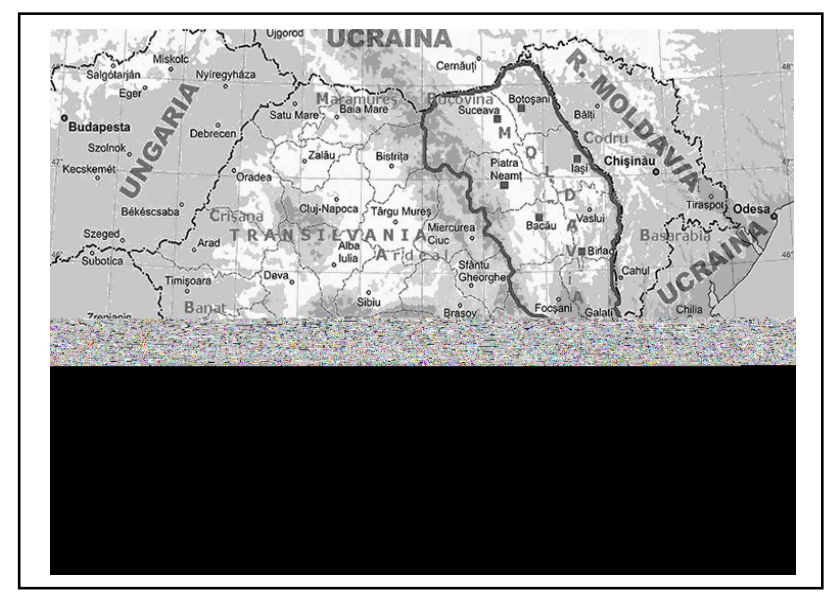

Fig. 1. Locations of weather stations in Moldavia region (Romania)

\section{RESULTS}

It can readily observe that, the periodic evolution of air temperature average values, throughout 22-year intervals in the 1945 to 2011 period, indicates a rising trend analyzed to all weather stations (Tab.1). The warming process was interrupted by a cold period (19671988), when, in Moldavia, the mean annual temperature decreased with approximatively $0,2^{\circ} \mathrm{C}$ or was constantely at the contact with Oriental Carpathians (Piatra Neamţ). 


\begin{tabular}{|c|c|c|c|}
\hline Period & $1945-1966$ & $1967-1988$ & $1989-2011$ \\
\hline Btations & 8.9 & 8.8 & 9.7 \\
\hline Suceava & 7.6 & 7.4 & 8.5 \\
\hline Iasi & 9.5 & 9.3 & 10.3 \\
\hline Piatra Neamt & 8.6 & 8.6 & 9.2 \\
\hline Bacau & 9.0 & 8.8 & 9.8 \\
\hline Birlad & 9.9 & 9.5 & 10.3 \\
\hline Galati & 10.7 & 10.3 & 11.4 \\
\hline Average & 9.2 & 9.0 & 9.9 \\
\hline
\end{tabular}

Tab. 1. The periodical average values of the air temperatures $\left({ }^{\circ} \mathrm{C}\right)$ recorded by the weather stations

Long-term trends, in 1945-2011 period (Fig. 2), of the evolution in the annual air temperature average values, show the same rising trend in Moldavia region as well.

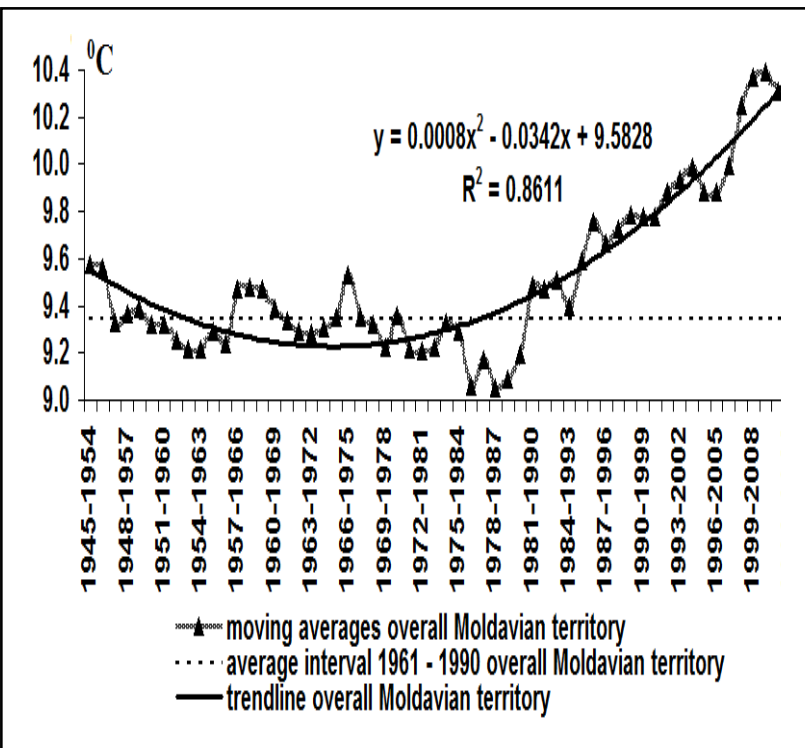

Fig. 2. The moving averages over a 10-year time series, shifted successively with one year of the annual air temperature average values overall Moldavian territory

Likewise long-term trends of the evolution in the annual extreme air temperature values, in 1945-2011 period (Fig. 3), shows overall Moldavian territory an increasing trend. The course of the maximum average temperature values is very similar to the annual average temperature values. Regarding the evolution of minimum temperatures we can say that linear upward trend is more clearly revealed.

The analysis of previous figures (Fig.2 and Fig. 3) show that, compared to the period 1961-1990 which have been defined by WMO the latest global standard normals period [8], in the first decade of $21^{\text {st }}$ century air temperature was $1^{0} \mathrm{C}$ higher.

Long-term trends (1945-2011) of the seasonal air temperature average values reveal that, during the cold semester, the temperature has a clear increasing trend, while in the warm semester, the air temperature average values shows an increasing trend in the last 35 years (Fig. 4).

An important characteristic of the thermal regime to a region, by default Moldavia (Romania), has been the frequency of days when it has been achieved, descended or exceeded thermal threshold of $-10,0,25$ or $30^{\circ} \mathrm{C}$.

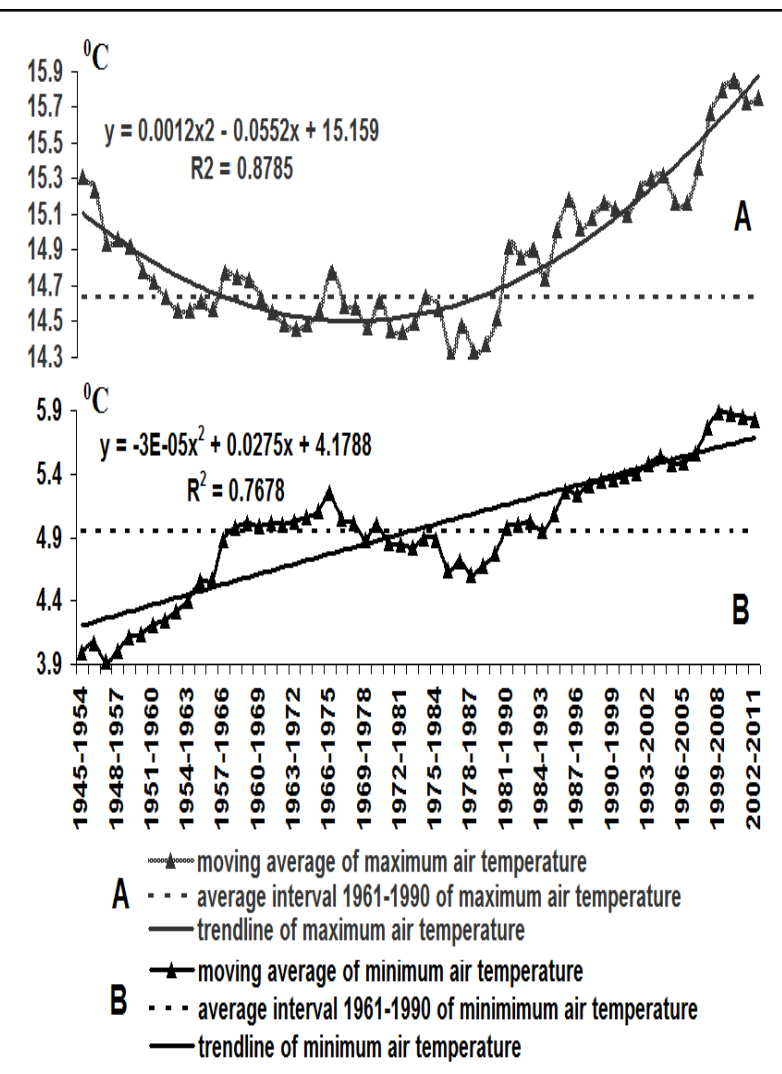

Fig. 3. The moving averages over a 10-year time series, shifted successively with one year of the annual maximum (A) and minimum (B) air temperature average values overall Moldavian territory

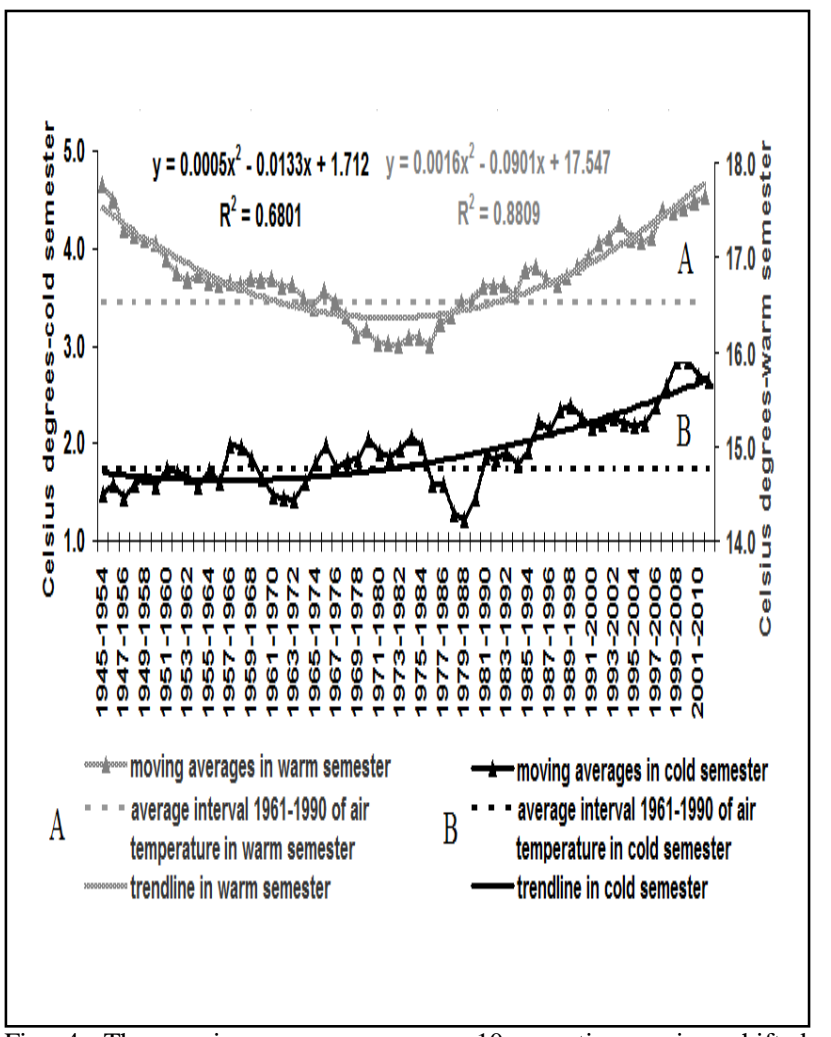

Fig. 4. The moving averages over a 10-year time series, shifted successively with one year of the semestrial air temperature average values overall Moldavian territory 
In the region of Moldavia (Romania) absolute extreme temperatures have occured as instantaneous values with unique character, indicating extreme limits possible between which the values of temperature can vary. Registering at long intervals without regularly, highs and lows absolute temperature are primarily a result of atmospheric circulation conditions, and secondly of the influence of local geographical factors.

The deepening winter cooling in the region of Moldova is favored not only by the advection of cold air masses but also their long time stagnation in this region. The maximum temperature occurs in the regime of higher atmospheric pressure, with clear skies and pronounced atmospheric stability, or in the case of invasion of continental air masses that come from southwest of the Asia continent or the northern African continent.

Absolute minimum temperature ever recorded in Moldavia was de $-35.0^{\circ} \mathrm{C}$ - and registered on February 1, 1937 in Iasi. The highest maximum air temperature was recorded on 22 July 2007 at Focsani weather station, its value being of $41.1^{\circ} \mathrm{C}$.

In the periodic evolution of the number of days with minimum air temperature $\leq-10^{\circ} \mathrm{C}$ (Fig 5), throughout 22-year intervals in the 1945 to 2011 period, indicates a decreasing trend analyzed to all weather stations. In the same figures 5, number of days with minimum air temperature $\geq 20^{\circ} \mathrm{C}$ show the rising trend in Moldavia region.

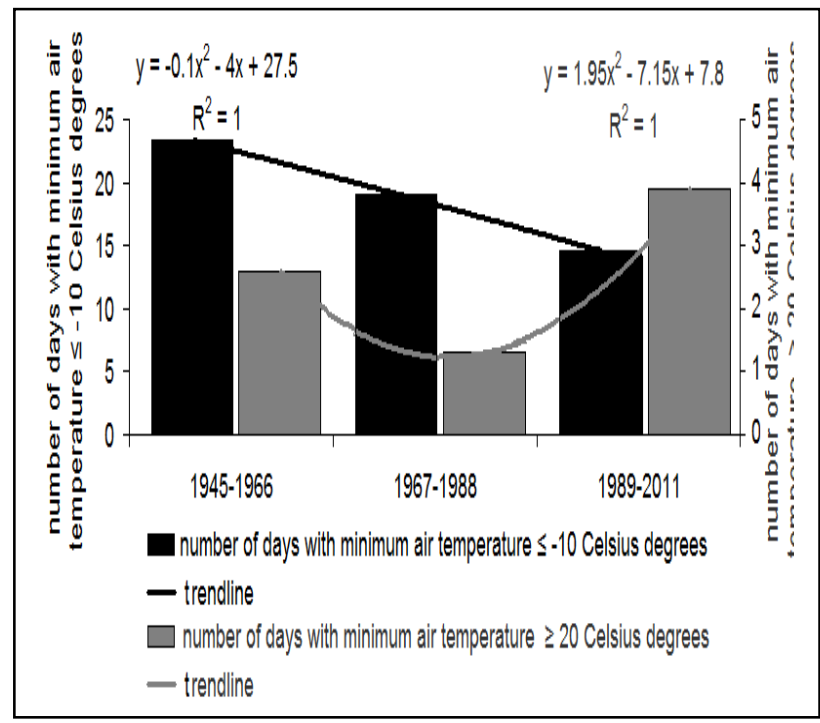

Fig. 5. The periodical average values of the number of days with minimum air temperature $\leq-10$ and $\geq 20^{\circ} \mathrm{C}$ overall Moldavian territory

As in the case of periodic evolution of the number of days with minimum air temperature $\leq-10^{\circ} \mathrm{C}$ (Fig. 5), one can observe that long-term evolution trend (1945-2011) of the the number of days with minimum air temperature $\leq-10^{\circ} \mathrm{C}$ and maximum/minimum air temperature $\leq 0^{\circ} \mathrm{C}$ shows an decreasing trend overall the Moldavian territory (Fig. 6, Fig 7).

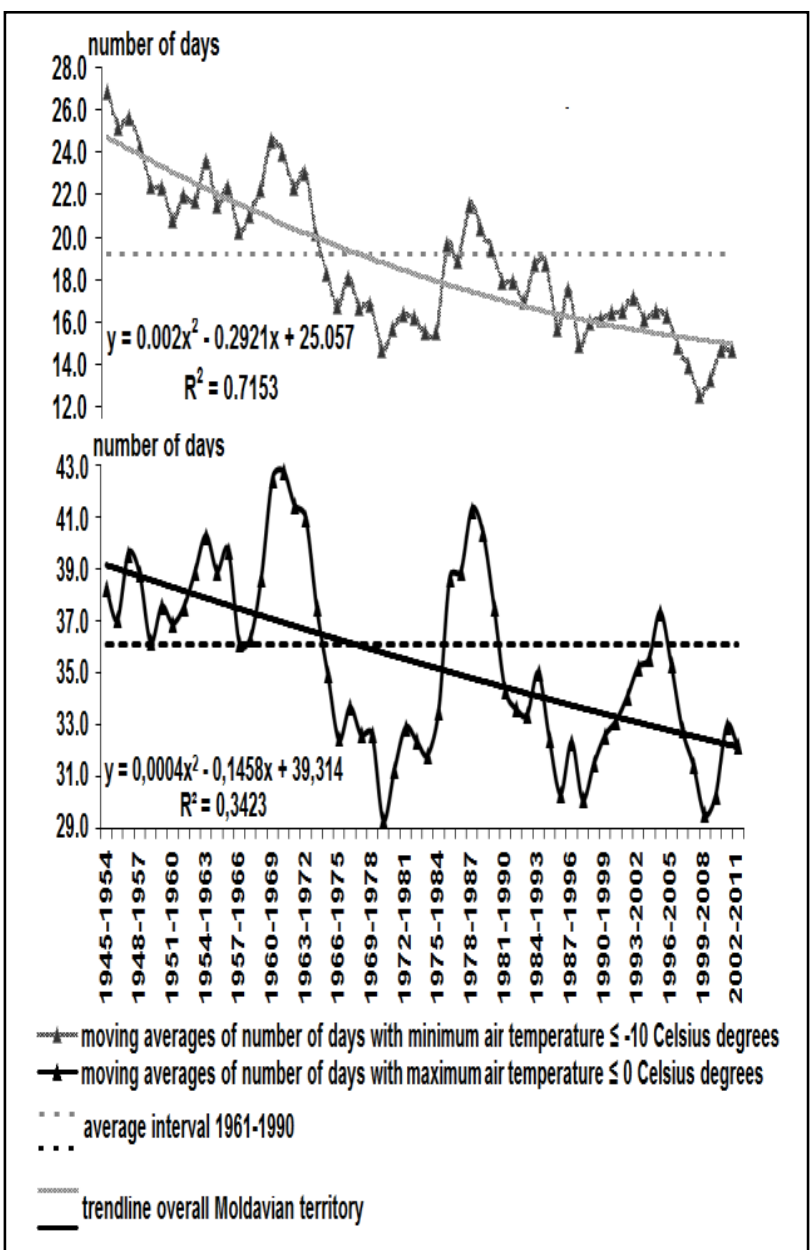

Fig. 6. The moving averages over a 10-year time series, shifted successively with one year of the number of days with minimum air temperature $\leq-10^{\circ} \mathrm{C}(\mathrm{A})$ and maximum air temperature $\leq 0^{\circ} \mathrm{C}$ (B) overall Moldavian territory

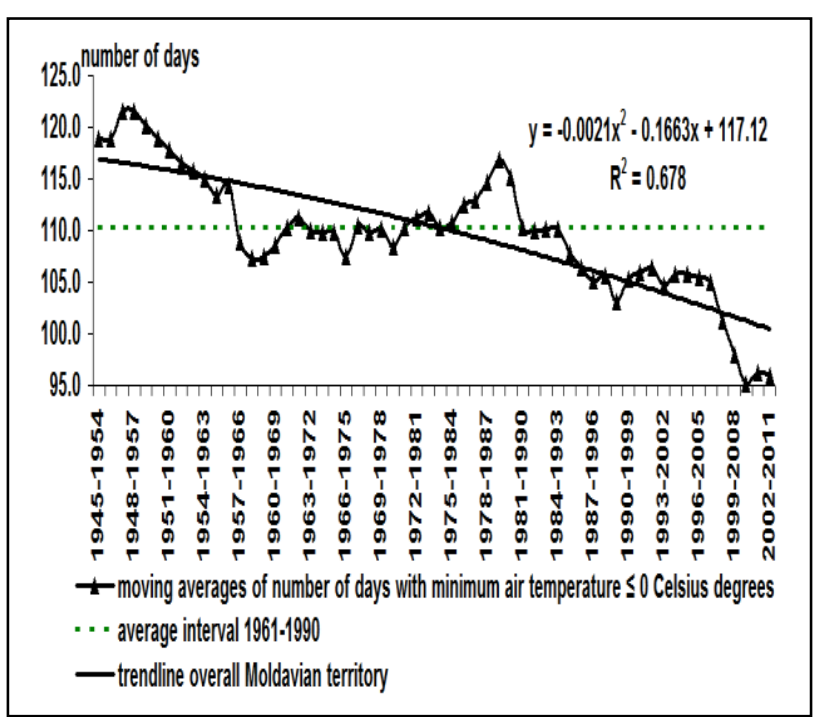

Fig. 7. The moving averages over a 10-year time series, shifted successively with one year of the number of days with minimum air temperature $\leq 0^{\circ} \mathrm{C}$ overall Moldavian territory 
Regarding the evolution of the number of days with maximum air temperature $\geq 30^{\circ} \mathrm{C}$ and minimum air temperature $\geq 20^{\circ} \mathrm{C}$, in $1945-2011$ period, we can say that in the first half of the range trend line is decreasing and then increasing (Fig. 8).

Compared to the period 1961 - 1990, in the first decade of $21^{\text {st }}$ century the number of days with maximum air temperature $\geq 30^{\circ} \mathrm{C}$ and minimum air temperature $\geq 20^{\circ} \mathrm{C}$ has doubled in the first case and tripled in the second case (Fig.8).

Considering those mentioned it can be appreciated that, at least in the last 40 years in Moldova (Romania), winters has weakened in intensity and are less cold and summer have became warmer.

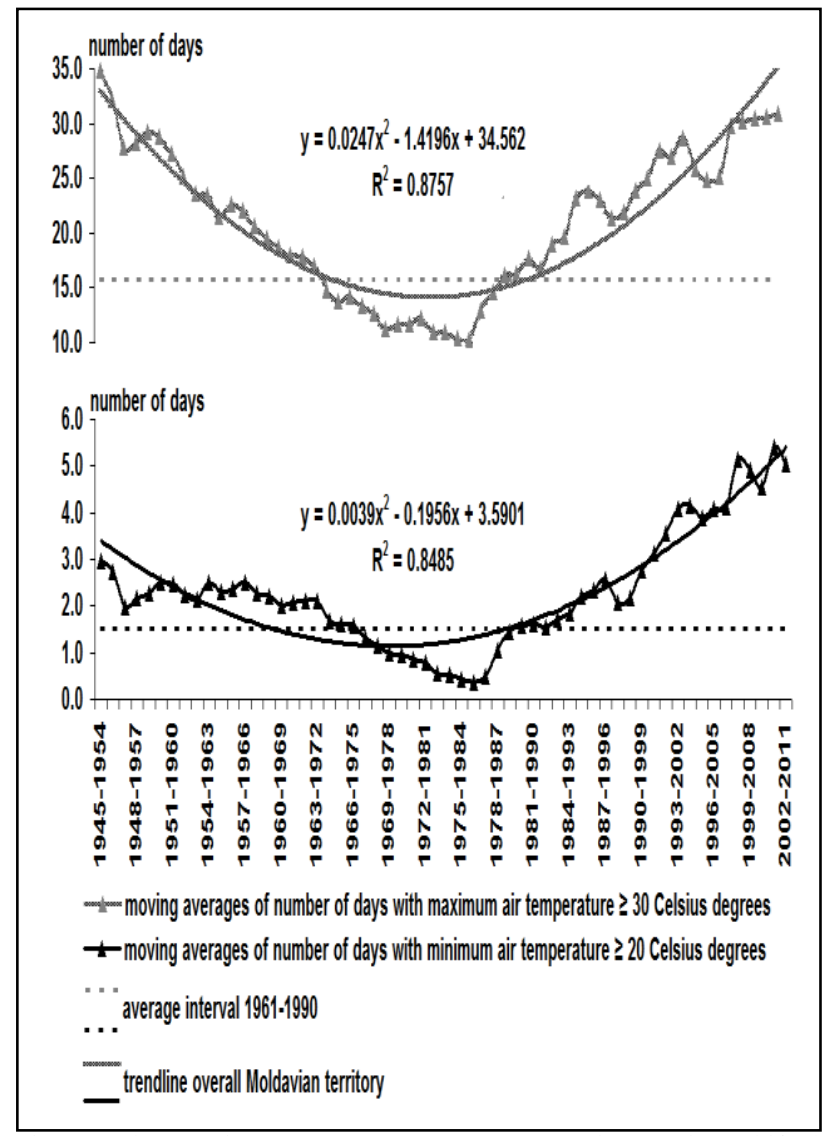

Fig. 8. The moving averages over a 10-year time series, shifted successively with one year of the number of days with maximum air temperature $\geq 30^{\circ} \mathrm{C}(\mathrm{A})$ and minimun air temperature $\geq 20^{\circ} \mathrm{C}$ (B) overall Moldavian territory

\section{CONCLUSION}

Calculations based on long sets of observations (1945-2011) have indicated that the annual air temperature average values show an increasing trend.

The number of days with minimum air temperature $\leq-10^{\circ} \mathrm{C}$ and maximum air temperature $\leq 0^{\circ} \mathrm{C}$ indicates a shift of the deviations towards the register of values below average. In terms of the number of days with maximum air temperature $\geq 30^{\circ} \mathrm{C}$ and minimum air temperature $\geq 20^{\circ} \mathrm{C}$, it has been found that the trend line had been increasing in the last 35 years.

Taking into account what we mentioned we can conclude that at least in the last 40 years in Moldova
(Romania), winters have weakened in intensity and are less cold and summer have became warmer.

Compared to the period 1961-1990 which have been defined by WMO the latest global standard normals period, in the first decade of $21^{\text {st }}$ century air temperature was $1^{0} \mathrm{C}$ higher and the number of days with maximum air temperature $\geq 30^{\circ} \mathrm{C}$ and minimum air temperature $\geq$ $20^{\circ} \mathrm{C}$ has doubled in the first case and tripled in the second case.

The averages of the last 67 years, in the hilly and plain region of Moldavia, at the East of the Oriental Carpathian, show a different increase, from $0,4^{\circ} \mathrm{C}$ (Suceava), at the $0,9^{\circ} \mathrm{C}$, conform with global and regional tendencies, but with specific pecularities.

\section{ACKNOWLEDGEMENTS}

Ovidiu-Miron Machidon is supported by a POSDRU grant no. 89/1.5/S/49944 "Developing the innovation capacity and improving the impact of research through post-doctoral programs", Alexandru Ioan Cuza University, Iasi. Climatic data were kindly provided by National Meteorological Administration of Romania Moldova Regional Meteorological Centre from Iaşi.

\section{REFERENCES}

[1] Apăvăloae, M., Apostol, L., Pîrvulescu, I. (1993), The analysis of the multiannual cicles of the air temperature variations in the Moldavia's Subcarpathians, "Geogr. Timisensis", vol. II, Univ. Timişoara, pg. 56-67, ISSN

[2] Apostol, L. (2004). The clima of the Moldavian Subcarpathians, Ed. Suceava University, ISBN 973-9408-81-8, Suceava

[3] Apostol, L., Apăvăloae, M. (2002), The annual averages of the air temperature in the Moldavia's Subcarpathians, Lucr. Staţ. „Stejarul”, ser. Geogr., vol. 10, Piatra Neamţ, pg. 5-16, ISSN

[4] Bâzâc, Gh., Cotariu, R. (1987), Estimations of the secular variation of the air temperature in a sector of the Northern hemisphere, Stud. Şi cercet de meteorolog., vol. 1, IMH, Bucureşti

[5] Ciulache, S., Ionac, Nicoleta (1994), General evolution trend of the air temperature in Romania, Anal. Univ. București, ser. Geogr., an XLII

[6] Hepites, St. (1898), Do the clima was changed?, Tipografia și fonderia de litere „Basilescu”, Bucureşti

[7] Iliescu, Maria Colette (1991), The secular variations of the air mean temperature on the territory of Romania, R.R.G., t.35, Edit. Academiei, Bucureşti

[8] Iliescu, Maria Colette (1992), The climatic tendencies on the Romania's territory, SCG, t. XXXIX, Edit. Academiei, București.

[9] Iliescu, Maria Colette (1994), The tendence of the long time variation of the air temperature in the Romania's territory, RRG, t. 38, Edit. Acedemiei, Bucureşti

[10] Mihaila, D. (2006). Plain of Moldavia - climatic study, Ed. Suceava University, ISBN 973-666-219-5, Suceava

[11] *** (2008), Climate of Romania, Ed. Academiei Romane, ISBN 978-973-27-1674-8, National Administration of Meteorology, Bucharest

[12] *** (1945-2011), Meteorological Tables TM1-1M, from the archive of Regional Meteorological Centre of Moldavia (Romania), Iasi

[13] http://www.wmo.int/datastat/wmodata_en.html, (2012), World Meteorological Organization, Accesed on:2012-08-10 